\title{
IMPACT OF STUDENT LOAN IN EMPOWERMENT THE COMMUNITIES
}

\author{
Bella Ghia Dimmera \\ Shanti Bhuana College of Management \\ Email: bellaghia@shantibhuana.ac.id
}

\begin{abstract}
This study aims to collect and analyze articles related to the impacts of student loan in realizing community empowerment. The background of this study is higher education costs cannot be afforded by the majority community. Although many government have launched student loan programs, the debate over failure of student loan programs in developing countries has not been resolved. The method used in this study is a literature review by collecting various sources of articles related to the issues discussed. Based on the articles collected, there are many problems such as irrelevant student loan policies, challenges in their application system, loans that could not be repaid that eventually burdened the community. The role of the government, the trust of banks, and the commitment of the community are factors that determine the success rate of achieving this student loan.
\end{abstract}

Keywords: student loan, community empowerment, community commitment

\section{A. INTRODUCTION}

The need and the realization about the importance of education in the era of globalization is increasing. This condition makes the government increasingly strive to continue rolling out capital or capital outside the world of education. If you to look closely, the opportunity to get education at a higher level becomes classified in the class layer that only has political power and economic understanding. Thus, the government must strive to build national education system so that it will be affordable for the whole community.

Educational strategies need to be carefully thought out by national leaders to reach out to all circles. At this time there are a lot of things happening, education can be said to be low because of not qualified facilities. The study of educational problems from the perspective of the community, and related institutions, both private and government as stakeholders, can provide a solution for the government to formulate alternative programs as the basic capital of national development.
Educational development is the responsibility of the entire community. The government as an institution has the authority to organize the education ark. It must have a high responsibility in improving the quality of education, so that the development of education strategies in the future can be achieved. Therefore, the government must issue policies or programs that support the improvement of the education quality.

One of the strategies carried out by the government to face the challenges in getting the community to have an equitable education is by launching student loans. Student loans are a form of community empowerment. However, the concern arises with the existence of the student loans is that students who apply for loans cannot repay the debt, so that it will burden their financial life. In many cases there are many students who withdraw or drop out from their study because of unpredictable financial difficulties, especially the problems caused by higher tuition fees or lack of opportunities for students to find work while in college. 
This study only focuses on how community empowerment can be realized by looking at the impact of student loans. The spirit of the community to get a quality education does not eliminate the obligations and responsibilities of the government for the implementation of education, but also does not adversely affect the state's finances.

\section{B. METHOD}

The method used in this study is the literature review method. This method of literature review is carried out by collecting and reviewing articles related to the issues discussed critically. Data collection from various sources is done by descriptive analysis, which describes the data obtained regularly, and provides a better understanding so that it can be understood by the readers.

\section{RELEVANCE OF STUDENT LOAN POLICIES}

A student loan is a very important financing tool for people, especially students who have the desire to pursue higher education (Bertola and Hochguertel, 2005). Higher education costs that always increase every year tend to be inaccessible to people with low or limited economic levels. This is a strong reason for the government to implement a student loan program in realizing educational equity in Indonesia. The Minister of Research, Technology and Higher Education (Menristekdikti), Mohamad Nasir said that this program provided a new way to improve the quality of resources in Indonesia in the face of Sustainable Development Goals (SDGs) (\#SiaranPersKemenristekdikti, March 22, 2018). In an effort to achieve that, it means that the government can guarantee equal distribution of quality education and increase learning opportunities for everyone, without exception. Indeed, it is the responsibility of the government to fulfill the right of education to all Indonesian citizens.
During the time for of the New Order the student loan in Indonesia was known as the Indonesian Student Credit Program (KMI). However, the KMI program was suspended in 1982 due to various problems, one of which was that many loans were not repaid. Therefore, because of the failure of this program in the past it raised concerns about economic growth in Indonesia. It is a big challenge for the government to study the student loan policy so that every student who applies for a loan can take responsibility for his loan and the problems in the New Order era do not happen again. At the very least, the presence of the government can really be felt in improving the level of public welfare now, tomorrow and in the future. The formulation of student loan goals should not seek great profits from the distribution of loans to each student but to open up the maximum access so that they become skilled human resources, character, and ready to enter the workforce after obtaining higher education (Arwildayanto, 2018).

The Law of the Republic of Indonesia Number 12 of 2012 concerning Higher Education regulates in more detail what is and how the fulfillment of student rights. As stipulated in Article 76 as follows:

(1)The Government, Regional Government and / or Higher Education are obliged to fulfill the right of students who are economically disadvantaged to be able to complete their studies in accordance with academic regulations.

(2) Fulfillment of the Student's rights as referred to in paragraph (1) is done by giving:

a. scholarships to outstanding students;

b. assistance or freeing education fees; and / or

c. Interest-free loan funds that must be repaid after graduation and / or obtain employment. 
The evidence that the government has special attention regarding the fulfillment of student rights for example is mentioned in the section of the Act such as the meaning of "scholarship" is a form of education cost support provided to students in order to follow or complete higher education based on the main considerations, namely, students must have an achievement in when they graduate from school. Additionally, the meaning of "tuition assistance" is a form of educational cost support provided to students in order to be able to attend or complete higher education based on the main considerations namely, the student's family's economic capacity or their parents are limited. "Interest-free loan funds" also means that the loans received by students are without interest. In order to attend or complete higher education the students are obligationed to repay their loans after graduating from their study or after obtaining a job. Precisely, this Higher Education Law emphasizes the existence of loan facilities to students during their study, which are collateral-free and can be paid after graduating from college.

This student loan program has been operating in more than 70 countries around the world (Shen \& Ziderman, 2009) but this number always seems to increase every year. Examples of student loan programs that are funded by government funds or supported by the government are in Japan, Scandinavia and the United States, where the idea of students borrowing from the government funds to finance higher education began in the 1940s and 1950s (Woodhall, 2007). Other developed countries regulated loan programs in the 1960s, including Canada and several European countries. Therefore, the government considers this program to be a form of community empowerment program that has been successful in developing countries.

From the results of a comparative study between students in the UK and France it was found out that students in the UK made student loans their main source of finance to continue their tertiary education, while in French the student have their parents' contributions as their main source of finance. Therefore, student loans are the main loan component of students in the UK and France (Curtis and Klapper, 2005). Similarly, in Malaysia, student loans provided by PTPTN are the most dominant source of financial assistance for students, especially in private higher education institutions (Nor Rasyidah et al., 2009). Thus, in other countries the means to assist students to enjoy higher education is through student loans.

\section{CHALLENGES OF STUDENT LOAN}

In its history, the main purpose of student loan policy in developing countries is to broaden students' choices in choosing higher educational institutions as desired. For those who want to go to the best or even high quality school, all efforts will be made to achieve this goal. Most students who use the student loans to pursue their higher education never forget, that student loans have succeeded in helping millions of students invest in their education. Given the broad economic benefits for higher education, tuition financing with student loans can be a valuable investment (Avery \& Turner, 2012). However, when students fail in completing their education or drop out (DO), this will be a disproportionate financial burden for both the banking institution and the students themselves. Even worse, the student loans will cause tremendous social and economic effects, such as the number of universities that are closed due to the lack of operational costs, bankruptcy of lenders, and so on.

Of the 34 provinces in Indonesia in 2017, the number of students enrolled in State Universities was 2,211,668 and there were 7,378 students who were dropped out, dropped out of school, and resigned, thus the 
percentage of students who dropped out of school was $0.3 . \%$. Whereas in private tertiary institutions, the number of students enrolled was $4,712,843$ people and 187,798 DO students have dropped to $4.0 \%$ (Higher Education Statistics, 2017).

Based on the explanation above, it shows how complicated it is to describe a firm policy in implementing a student loan program. The cause of DO students cannot be denied due to financial or financial factors. Many students who take tertiary education choose to resign or DO because they are no longer able to pay for their tuition. However, the inability to pay for college tuition can also be caused by several things such as the inability of determining the current focus of study and work, a lifestyle that is too wasteful and can also be due to a decrease in the number of scholarships available to support students, especially those at the final level. The government policy regarding student loans as financing for higher education has a large influence on the allocation of resources in higher education and provides benefits that reach all circles of society (Rani, 2016). Given concerns about debt due to student loans, several policy changes have been proposed, generally focusing on one of three objectives: reducing post-tax tuition fees; reducing the debt burden on students, without having to change the amount of money owed; or restrict government support for educational institutions that cannot prepare their students for "lucrative employment." (Gale, W., Harris, B., Renaud, B., \& Rodihan, 2014).

As it is well known, the existence of a student loan problem is closely related to legal issues, this is because in the process of lending means establishing a relationship through an agreed agreement, which states that there is an obligation for students to return the loan they received. Meanwhile, students who applied for a loan is very optimistic about their future and thus potentially will have a great income. Students who accumulate debts also have the confidence that their current financial situation is only temporary and the debt will be paid off easily, so for them it is not a big problem. Every person with a higher level of education can be measured by the length of time for a school that should have a better job and income compared to people whose education is still low. The hope is that after graduation, there will be jobs, increased income, and automatically their debt will decrease. That way, students did not care less about the length of time of the debt to be paid and they were confident they could carry out the obligation to pay off the debt. Because there is a sense of responsibility, surely the student dares to agree on agreements with the related parties, and before going through a process of considerations first, as well as their awareness and vigilance before taking the decision to get into debt.

\section{E. POLEMICS OF DEBT}

Policymakers and universities must recognize that financing options for investment in human capital with debt are not dangerous, and can reduce the relative level of human capital to alternatives that do not tighten loan restrictions (Liberman and Yannelis, 2017). In this case, demonstrating that human capital will indirectly help the government in several fields, especially in the field of education, among others, utilize the available resources and be able to harmonize policies with investments that are more focused on results. This student loan contributes to encouraging the government to invest in the development of human capital, because it is very important to help preparing the public to be able to compete and continue to grow in the future of the economic growth that is constantly changing. Just as human quality is getting better in education, it will have a big influence on increasing the efficiency and productivity of a country. Modern economic world are increasingly dependent on economic activities related to science. This is why community capital will 
play a more important role in determining long-term economic growth, but also a serious threat to the prosperity of the future of developed countries (Stiglitz, 2013).

The important thing that must be considered before implementing a student loan program is to realize the lifestyle of the millennial community at this time. Related to the lifestyle of students who tend to be hedonic, especially those who study in urban areas should emphasize more stringent requirements in the process of obtaining loans. Student loan must be used according to its function, namely for the cost of education, not just to fulfill the desire of life that is full of luxury. The banking sector must firmly provide loans with a clear legal basis in its implementation, and provide loans in accordance with the needs of students for tuition fees charged by universities and their economic capabilities. There is a need to formulate a decision strategy on lending, and must pay more attention to the behavior of students who will apply for a loan.

The increasing phenomenon of debt in developing countries with the existence of student loan programs makes some people pessimistic. Critical conversation about debt never ends. There is an assumption that debt often makes students trapped in an increasingly choking economic situation. However, basically the decision to apply for a loan or not is on the students themselves. In this case the government only helps Indonesians who want to attend college but are hindered by high costs. The decision to finance higher education through debt must have a limit to how much funds are used on the basis of financial benefits that can be obtained from the debt.

In this situation the government can play an active role to encourage the development of national education. This student loan program is very helpful for students, especially students who will complete their study at the final level, but their parents cannot pay the tuition fees. There must be an agreement between the government and the banking sector, that education should not be poisoned with a mere market nuance, as well as profit-oriented universities. The message of this educational corporation ultimately made the practice of education experience irregularities and violations.

\section{F. PROCESS OF COMMUNITY EMPOWERMENT}

The factors that influence student's planning to carry out higher education include: parents education level, parental work, family annual income, various universities and student loan programs, and the impact of student loans is the largest (Bing, 2012). In fact, the low level of parents education of will directly or indirectly affect the work and the level of income earned both from the main job and side jobs of their parents within one year, so that the work of parents is behind the consequences of the size of the family's socioeconomic level. The family's economic level can also determine their children's interest in improving education to a higher level. For families whose economic level is below the poverty line, the interest in pursuing higher education is lower than those in the upper-class economy. In addition, differences in the family backgrounds also affect the students in choosing the type of college to attend. In this case that always triggers a gap in the community. Responding to this, it must be admitted that the community has little opportunity to pursue higher education because of the low economic capacity of the community. In contrast to people with higher economic levels, they can choose any college as they wish. Thus, it is clear that the reason for students to apply for loans is because of the economic pressure, so that most students prefer to look for a job after graduation so they can repay their debts to ease the burden on their family or parents as soon as possible. 
Basically, student loans are given to students from the lower economic class. If those who apply for student loans are on the basis of poverty, then the application for loans for education fees will not be rejected. An understanding of how, why, and what kind of students who apply for loans is very important in regulating the student loan system so as not to be burdened with the obligation to pay taxes so as to better support student success (Cellini, 2016). This is an opportunity for everyone to invest it education to have a better future with financial assistance when they need it and are responsible for returning the money by paying off the debt. The majority of tertiary education graduates can expect a much higher life span, earn a higher income, as a result of their education, they also benefit higher than average income because they cannot be subsidized by taxpayers with an average income or below average (Mussa, 2015). In general, the application of income-based student loans can work well if the country has an effective tax system and is always growing rapidly, namely the income of all people reported and documented in the government.

Education is increasingly expensive, it is also not only caused by people's failure to fulfill their obligations. The number of tertiary institutions with high tuition fees and there will be foreign universities, of course, will create an educational institution that has a market-oriented management process in order to be able to improve the quality of education through the development of various educational facilities. This condition makes education be more to be afforded difficult to be reached by poor people. People must begin to depend on their financial capacity to get better quality of education. Student loans without interest will be more ideal to encourage higher education participation and can assist people to invest in education. Student loan is not a necessity or the main requirement to get a tertiary education. This is only a choice, and also as a financial solution for students (Hardinawati, 2017). For this reason, it would be wise if the banks also actively held socialization activities on how to do financial planning for borrowers of education funds for the next several decades. So, borrowers of education funds also know what the consequences are, so that they are not only limited to exposing sanctions and lending processes, extension of financial readiness must also be explained. In other words, banks have carried out one of their responsibilities, which is to provide clarity on how the students must commit to settle their debts.

\section{G. CONCLUSION}

This study explains the impact of student loans in community empowerment with related issues such as irrelevance of policy, the debate on the many challenges, loan dependence that has the effect of accumulating debt, and the process of improving the level of community welfare. The community empowerment which is based on efforts to distribute education will improve the quality of society. In this case, the government and the banking sector must work together in making pro-community policies.

In essence, it is not easy for the government to implement student loans with policies that are as perfect as possible, as well as the banks in anticipating non-performing loan ratios, without having to prioritize profits. This is only one solution to help people with limited economic capacity, and have big dreams to pursue higher education. The success rate of avoiding debt accumulation and debt repayment in accordance with a predetermined period of time depends on the commitment of the community to try to meet the agreed conditions. 


\section{H. REFERENCE}

Arwildayanto. (2018). Formulation of Higher Education Financing through the Distribution of Education Loans for Students. National Seminar on Educational Education and Management Administration. April 21, 2018, Hotel Remcy, Makassar. P. 175-184.

Avery, C., \& Turner, S. (2012). Student loans: Do college students borrow too much or not enough? The Journal of Economic Perspectives, 26(1), 165-192.

Bertola, G. and Hochguertel, S. (2005) Household Debt and Credit. European University Institute Working Paper.

Bing, Z. (2012) 'A Study of State Educational Loan Demand Diversity and its Influencing Paths-An Empirical Analysis based on SEM Model', Energy Procedia, 17, pp. 1932-1939. doi: 10.1016/j.egypro.2012.02.335.

Cellini, S. and R. D. (2016) 'Different degrees of debt: Student borrowing in the forprofit, nonprofit, and public sectors', Brown Center on Education Policy, (June), p. ix, 106.

Curtis, S. and Klapper, R. (2005) Financial support systems: the student experience in England and France. International Journal of Social Economics. Vol. 32 Iss: 1/2, 121 - 132.

Gale, W., Harris, B., Renaud, B., \& Rodihan, K. (2014) 'Student Loans Rising', (May), pp. 1-10. Available at:

https://www.urban.org/sites/default/files/publ ication/22591/413123-Student-Loans-

Rising.PDF.

Hardinawati, L. U. (2017) 'Student Loan as a Funding Solution for College Student in Indonesia', (July).

Kemenristekdikti. (2017). Higher Education Statistics. Pusdatin Dikti Science and Technology. Jakarta.
Liberman, A. and Yannelis, C. (2017) 'I . Introduction', Debt and Human Capital: Evidence from Student Loans, (January), pp. $1-9$. Available at: http://www.eief.it/files/2017/06/liberman.pdf.

Mussa, A. (2015) 'Sustainability of Higher Education Students' Loan Scheme ( HESLS ) in Tanzania', European Journal of Business and Management, 7(9), pp. 149-164. Available at: https://www.iiste.org/Journals/index.php/EJB M/article/viewFile/21197/21541.

Nada Marsudi. 22 Maret 2018. Menristekdikti Appreciation of BRI Launches Student Products, \#SiaranPersKemenristekdikti https://plus.google.com/10747478462221897 8814/posts/bmgg9tdvX7T. Accessed September 28, 2018.

Nor Rashidah Zainal, Siti Badariah Saiful Nathan, Rohana Kamauddin, Kamaruzzaman Jusoff. (2009). Socio-economic status and parental savings for higher education among Malaysia Bumiputera families. International Journal of Economics and Finance. Volume 1, No2.

Rani, P. G. (2016) 'Financing Higher Education and Education Loans in India: Trends and Troubles', Journal of Social Sciences, 12(4), pp. 182-200. doi: 10.3844/jssp.2016.182.200.

Shen, H \& Ziderman, A. (2009) Student Loans: Repayment and Recovery: International Comparisons.\| Higher Education. Vol. 57, pp. 315-333.

Undang-Undang Republik Indonesia Nomor 12 Tahun 2012 tentang Pendidikan Tinggi. Pasal 76 ayat 1-2.

Stiglitz, J.E., 2013. Student debt and the crushing of the American dream. The New York Times, May 12th. 
Woodhall, M. (2007). "Student Loans in Developing Countries: Feasibility, Experience and Prospects for Reform." Higher Education 23 (4):347-356.

Yannelis, C. (2016) 'Strategic Default on Student Loans *', Working Papers,
(February). Available at:

http://faculty.chicagobooth.edu/workshops/fi nancelunch/past/pdf/Strategic Default.pdf. 